\title{
A Normative Model for Regional University Network Collaboration in Education
}

\author{
Arne Jensen, Rickard Bergqvist \\ Logistics and Transport Research Group, Department of Business Administration, School of Business, \\ Economics and Law at University of Gothenburg, Gothenburg, Sweden \\ Email: arne.jensen@handels.gu.se
}

Received September $3^{\text {rd }}$, 2012; revised October $4^{\text {th }}, 2012$; accepted October $18^{\text {th }}, 2012$

\begin{abstract}
Increasing demand for more specialized courses and programs increases the need for universities to differentiate their educational offer and portfolio. Increasing the course portfolio combined with small student populations and at the same time ensuring high quality is a difficult challenge for most universities given their budget limitation and the access they have to educators in the specialized disciplines within their own organization. Pooling, coordination and utilization of resources through network creation and university collaborations is one option for coping with this challenge. This paper develops a normative model for intraregional university network collaboration in education aiming at preparing students for work in a particular industry. The paper deals with network organization, principles of operation, course structure, course delivery, and supporting activities.
\end{abstract}

Keywords: University Network; University Collaboration; Normative Model; Educational Coordination

\section{Introduction}

Increasingly, universities feel pressures from various sources to increase the effectiveness and efficiency of their educational activities. This situation is particularly obvious in education aiming at preparing students for work in industrial sectors where the global competition is strong. For such sectors, increasing competence of the human capital is seen as a prerequisite by many for coping with future economic, environmental, and social challenges.

This creates problems for general universities, since it forces them to respond by offering more courses and study programs with specialized content of high academic quality in order to preparing their output, the students, for work in industrial sectors having demand for specialized academic knowledge among their employees. However, differentiating the portfolio of courses for small student populations and at the same time raising course quality is an equation which is difficult to solve for most universities considering their budget limitations and the access they have to educators in small and specialized academic disciplines in their own organizations. Collaboration between universities in small specialized educational sectors, where the collaborating partners create arrangements for pooling, coordinating and utilizing their resources collectively, is one option for offering specialized education of high quality in a costefficient way. When talking about university networks in this context, it is important to understand that such networks in most cases will consist of one department or, more likely, a sub-unit within one department from each university. It is also important to understand that participating partners in a network of this kind can't be too different in terms of culture, language, education methods, and industrial needs of competence development.

This paper develops a normative model for regional university network collaboration in education for the maritime sector.
We hope that our model can give guidance in similar network development initiatives. We will use the abbreviation RMUN (Regional Maritime University Network) for university networks having this purpose. The maritime sector is taken here to include the shipping industry, the port industry, the off-shore industry, the fishery industry and also national, supra-national, and local regulative administrations for these industries. The paper deals with strategic network design, network organization and management, principles of operation, course structure, course delivery, and supporting activities.

Empirically, our paper is based on work we have done in the Interreg IV B project "Northern Maritime University (NMU)", a research project in which various conditions for university collaboration among universities (See “Acknowledgements") offering maritime courses were studied and several collaborative course arrangements tested. The empirical focus of the NMU project was the maritime industry of the North Sea Region and its future needs of educated academics.

Methodologically, the research of our present paper uses an instrumental case study approach (Stake, 1995) of the temporary NMU network for drawing normative conclusions. The NMU network was put together for research purposes. In our present paper, data collection from several sources of information has been used such as direct observations, participant observations, interviews, documents, and archival records (Yin, 1989). We are convinced that our case is sufficiently representative in relevant dimensions for other maritime regions as well, which explains our choice of developing a normative model for regional maritime university network collaboration. We think that our normative RMUN model can be applied to other university-industry dyads as well and not only to the maritime sector. Despite this argued generality, we have retained some maritime terminology in order not to over-abstract the subject and losing its empirical flavor entirely. The few maritime terms we use can easily be translated to or interpreted for other uni- 
versity-industry relationships.

Our theoretical frame of reference is taken from business administration and management since business administration is our scientific "domicile". The parts of business administration we refer to belong mainly to strategic market management, a subject which is well spelt out in Aaker (2001) and Kotler and Keller (2006). Our theoretical framework is used instrumentally for structuring, organizing and explaining the model we are developing.

\section{Mission}

The theory of strategic management emphasizes the formulation of a mission statement as guidance for founding, designing and managing an organization. We suggest that the mission of the type of regional university network collaboration in education referred to in this paper is formulated as: Coordinating, pooling and utilizing the collaborating partners' key resources collectively for strengthening the sustainability, competitiveness and innovativeness of the industrial sector served by the partners by:

- offering students and course providers at universities and in industry a broad range of innovative courses and course components of high academic quality in business management reflecting industrial needs of the sector and according to regional university requirements for issuing grades and exams (Mission 1);

- offering the sector and universities improved access to scientific expertise in subjects supporting business management and public regulation of the chosen industrial sector (Mission 2);

- organizing the skills, experiences and competences of RMUN partners for undertaking common industrial and educational $R \& D$ projects in business management and public regulation related to the chosen industrial sector (Mission 3);

Continuous collaboration among partners will be a fundamental driving force for accomplishing RMUN missions as described above. It can, therefore, be considered as an important mission in itself.

\section{Organization and Principles of Operation}

\section{Organization}

Regional university network collaboration in education is proposed to be led by a coordinating unit, the task of which is to utilize, develop, and manage the physical and intellectual resources and rights that the members place at the network's disposal according to a network agreement. There are several ways of organizing the coordinating unit. It is suggested here to have a board responsible for policy and decision-making and a secretariat for implementation and administration led by a RMUN coordinator. The central coordinating unit should be either placed with one partner or decentralized by placing the secretariat and the coordinator with one partner and the web site with another.

In functional terms it is suggested here to organize RMUNs in two strategic business units (SBUs) under the central coordinating unit, SBU1 and SBU2. SBU1 is responsible for fulfilling Mission 1 and SBU2 for Missions 2 and 3. SBU1 represents the core activities of RMUNs and SBU2 two important support activities for up-dating and developing the core activity: scientifically based education. The activities of the two strategic business units are interrelated and they will both, in a longer perspective, contribute to making RMUN type of organizations leading academic networks for innovative education and R\&D. In commercial contexts, a strategic business unit is an independent profit centre having a strategy of its own. This model, when applicable, should be imitated by RMUNs. Business unit strategies, however, must support overall organizational strategy. It is the responsibility of the board of the network to harmonize strategy implementation if necessary. Figure 1 shows the proposed RMUN governance structure and the organization of the main RMUN activities.

The SBUs are functions responsible for coordinating various fixed and virtual resources to a basic preparedness for service production and marketing as defined in the RMUN network agreement. Most service provision will be carried out decentralized by network partners, either individually or in small groups. The central unit and the SBUs can be located either together or at different partners and rotated between them in order to stimulate collaboration.

\section{RMUN as Subcontractor}

It is important to understand that RMUN services will be delivered by RMUN members to their final markets as one of perhaps several components in the members' service packages. These packages will normally be marketed and delivered in the name of the members, the universities, in their on-going activities and not primarily in the name of RMUNs. In this sense, a RMUN will be a subcontractor to its members. It will work in direct transaction channels (RMUN to final user/consumer) only to regional or global markets and only if agreed upon among RMUN members. This role of being a "subcontractor" to its members has two important implications. The first implication is that a RMUN will not deliver services directly to its final markets in competition with its members.

\section{The RMUN Brand}

In order for a RMUN to survive in a longer perspective, its brand must be well known and attractive to both customers and final markets. This can only happen, if the services of the network simultaneously are capable of adding value to both RMUN customers and the final markets. RMUN members must consider it as cost efficient, flexible and demand creating to inte-

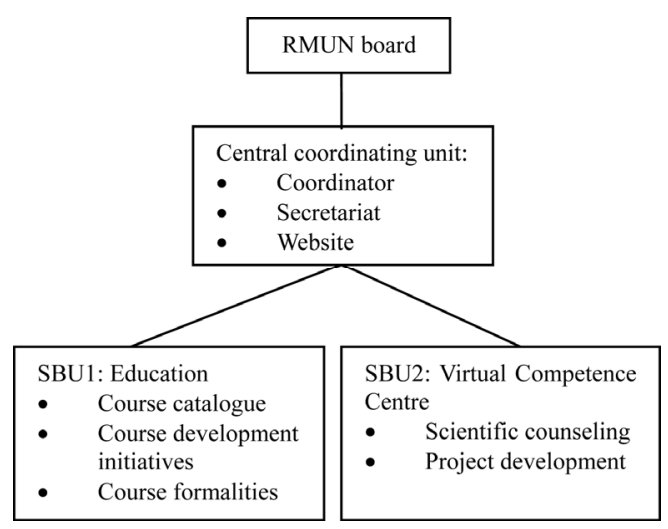

Figure 1.

Proposed RMUN organization. 
grate RMUN services in their output where relevant, and the final users, the consumers, must find RMUN members' service outputs more valuable and useful with, than without, RMUN services.

This calls for high quality in both the design and delivery of RMUN services. It also calls for high quality of the context, the service packages, in which RMUN services are integrated. There may be quality interdependencies between the RMUN services as such and their delivery contexts which must be addressed, if the ambition is to build and maintain a strong RMUN brand (e.g., if a teacher is using a RMUN course component as part of a badly managed, and badly taught, course for industry). These quality aspects will have to be under continuous review.

The RMUN web site is an important tool for communicating the RMUN brand, for marketing, and for operational order mediation and service delivery. Therefore the responsibility for the website is placed at the central coordinating unit.

\section{Product Mix}

The RMUN product mix consists of services organized in three product-lines: education, scientific counseling, and project development. Scientific counseling and project development are components of the RMUN Virtual Competence Centre, the design of which is developed in the present chapter.

\section{Education}

Education is the key product-line in the RMUN product mix. The educational offer consists of a system of modules. A module has a natural coverage and content in terms of learning objectives, as well as in terms of theoretical origin and practical relevance. A module thus constitutes what is normally understood as a course in the language of the academic community.

\section{Module Structure and Content}

It's important that RMUN modules follow the rules in terms of size and quality for issuing grades (e.g., Bachelor and Master grades) in the region to which RMUN partners belong. For regions in Europe, RMUN modules should follow the requirements of the Bologna principles. Here modules should have a size of 7.5 ECTS credit points and are made up from five module elements (MEs) of 1.5 ECTS credit points. The MEs are the smallest elementary components in the course system. They must allow flexible use as fundamental building blocks. MEs are normally developed and used in the context of a module, but a given ME may occasionally also have a stand-alone use for other educational purposes or be used in more than one module. European RMUNs should only develop and offer modules and MEs of size 7.5 ECTS and 1.5 ECTS respectively. All modules and MEs in the RMUN product-line for courses for courses have to follow RMUN quality criteria, among them the Bologna principles and requirements.

A set of RMUN modules should be possible to use for designing course programs for specific careers or labor markets. Such modules should exist for both the Bachelor level and the Master level.

Each ME should be developed, owned, and provided on demand by one or more of the RMUN university members as long as it exists in the RMUN product mix. It is the responsibility of ME owners to update their MEs over time. RMUN members will develop new MEs and modules according to the standards prescribed in their network agreement when sector needs and member capabilities coincide.

\section{Course Delivery}

There are three basic modes of delivery by which a ME owner can deliver the content of a ME (Franklin and Peat, 2001):

- Conventional face-to-face classroom teaching at the ME owner's campus;

- Via the Internet as e-teaching;

- Conventional face-to-face classroom teaching by the ME owner as a visiting lecturer-traveling lecture concept.

In many cases, a combination of two or three of these modes of delivery will be used which leads to a forth category:

Blended teaching (Garrison and Kanuka, 2004; Osguthorpe and Graham, 2003). Blended teaching differentiates the RMUN brand from many competing alternatives.

The combination of modes actually offered for a given ME is the choice of the ME owner. These modes of delivery can be combined with exchange of students between universities where students study one or several MEs at another campus during a short period of time. This kind of flexible, goal-oriented, course based student exchange will add a new creative dimension to regular student exchange programs and policies (Shaheen, 2010), for example in Europe.

The ME owner must take responsibility for examining and grading students of a ME according to RMUN requirements. However, the formal use of these grades in a wider educational context such as in various academic degrees is the responsibility of the university or organization issuing the degrees and not of the ME owner that delivers the ME.

\section{Customers}

RMUN customers refer to organizations to which RMUN partners will sell course services. These organizations can be considered as resellers or distributors in the RMUN marketing channel for courses. The services are delivered by RMUN ME owners at locations chosen by the resellers and delivered there to the resellers' service consumers. A consumer is a recipient of the educational act or process. In commercial terms we have two transactions, between RMUN partners and their customers and between these customers and the final consumers, the students. RMUN partners will normally also distribute courses directly to consumers (direct distribution) in their own consumer segments such as to their own students.

In production terms the service will be provided and delivered by the RMUN ME owner to the final consumer in an interactive process. The consumer is the RMUN customer's customer if distribution is indirect. The actors in the RMUN marketing channel for courses are summarized in Table 1, where the terms target customers and target consumers refer to both existing and potential such actors.

\section{Value Added}

The task of the RMUN course services is to deliver educational value to customers and consumers by increasing the competitiveness of both in their respective market places. In a generic sense, the RMUN network can deliver value to customers by increasing their ability to offer such courses and educational programs which they are unable to produce themselves without access to the kind of subcontractor services offered by 
Table 1.

RMUN marketing channel actors.

\begin{tabular}{|c|c|}
\hline \multicolumn{2}{|c|}{ RMUN marketing channel actors } \\
\hline RMUN target customers & RMUN target consumers \\
\hline University customers: & University students in: \\
\hline $\begin{array}{l}\text { Course developers and course } \\
\text { leaders in logistics and transport } \\
\text { economics and management and } \\
\text { other subjects relevant to the } \\
\text { maritime transport sector }\end{array}$ & $\begin{array}{l}\text { - Logistics and transport } \\
\text { - Other subjects relevant to the } \\
\text { maritime transport sector such } \\
\text { as international trade and } \\
\text { international business }\end{array}$ \\
\hline & Industry students: \\
\hline $\begin{array}{l}\text { Industry customers: } \\
\text { Competence managers and } \\
\text { developers in the maritime } \\
\text { transport sector }\end{array}$ & $\begin{array}{l}\text { Industry students from the } \\
\text { maritime transport sector in } \\
\text { need of competence } \\
\text { development }\end{array}$ \\
\hline
\end{tabular}

RMUN. There can be several explanations for their difficulties. RMUN can deliver added value to customers and consumers by offering:

- Specialized modules and module elements (MEs) of high quality for the maritime sector, courses that target customers are unable to produce themselves because of lack of expertise or financial resources for developing and running such courses;

- Modules and MEs made available to customers when and where they need them. This means that RMUN education services must be possible to integrate in a flexible way in the educational production cycles of the customers;

- Modules and MEs that consumers find interesting and stimulating to study;

- Modules and MEs that are expected by consumers to be competitive in their labor markets;

- Flexible and differentiated teaching and learning methods.

These characteristics can be seen as specific generic "value adders" which are important for future RMUN course development and delivery. They differ in importance for different customer and consumer segments. They have been applied in the development processes of the RMUN project. In addition to these specific factors as "value adders", a strong RMUN brand will in a more general sense add value to any customer/consumer who is permitted to distribute/consume RMUN products.

\section{Scientific Counseling}

Scientific counseling is one of the services of the RMUN Virtual Competence Centre, strategic business unit 2 (SBU 2). It is a manifestation of the second mission of the RMUN.

\section{Service Definition}

The RMUN scientific counseling service offers external and internal users to draw on the collective skills, experiences and competences of the RMUN members as scientific experts in subjects related to business management in the maritime sector. Possible services include inputs to maritime transport decision processes in industry and public management as well as advisory educational services to universities and companies such as development of in house management training programs in industry and supervision of thesis work at universities.

\section{Service Delivery}

RMUN partners should appoint their own experts within a predefined set of scientific fields of competence according to their internal policies and RMUN requirements. Names of experts of each RMUN partner are available on the online portal of the RMUN Virtual Competence Centre under "Part A, Scientific Counseling”. Experts are categorized in a way which facilitates for clients to identify and contact the correct expert. The predefined set of scientific fields of competence is shown in Table 2.

Each RMUN partner university wanting to participate in RMUN scientific counseling will be offered a template for expert identification like the one shown in Table 2 . It is the responsibility of the partner to maintain and update the template. A unique key to the template will be given to each participating partner by the RMUN secretariat.

\section{Customers}

Operationally, customers could be defined as anyone in need of scientific advice or knowledge related to business management in the maritime transport sector. In nominal terms, the potential clients for scientific counseling are widespread over several sectors in society and therefore difficult to specify. Table 3 gives an overview of target customer categories and target customer representatives for scientific counseling.

\section{Value Added}

The objective of RMUN scientific counseling as defined above is to deliver value to customers by offering scientific knowledge and expertise that:

- can be found directly without long search processes;

- is supported by theory and/or scientific studies;

- provided by researchers who meet RMUN and member quality criteria;

- is objective and free from vested interests and following RMUN and university rules of ethics.

Table 2.

RMUN virtual competence centre. Part A, Scientific counseling. Template for expert identification. RMUN member:

\begin{tabular}{|c|c|c|}
\hline Application & Scientific fields of competence & $\begin{array}{c}\text { Names of } \\
\text { experts }\end{array}$ \\
\hline \multirow{3}{*}{$\begin{array}{l}\text { Company } \\
\text { strategy }\end{array}$} & (1.1) Analysis of freight markets & \\
\hline & (1.2) Analysis of competition & \\
\hline & $\begin{array}{l}\text { (1.3) Company overall and } \\
\text { functional strategies }\end{array}$ & \\
\hline \multirow{4}{*}{$\begin{array}{l}\text { Government } \\
\text { strategy }\end{array}$} & $\begin{array}{l}\text { (2.1) Regulation/deregulation and } \\
\text { efficiency }\end{array}$ & \\
\hline & (2.2) Transport policy measures & \\
\hline & $\begin{array}{l}\text { (2.3) Environmental policy } \\
\text { measures }\end{array}$ & \\
\hline & (2.4) Maritime and transport law & \\
\hline \multirow{3}{*}{$\begin{array}{c}\text { Transport } \\
\text { chain design } \\
\text { and manage- } \\
\text { ment }\end{array}$} & (3.1) Port management & \\
\hline & $\begin{array}{l}\text { (3.2) Technologies of shipping seg- } \\
\text { ments and ship types }\end{array}$ & \\
\hline & $\begin{array}{l}\text { (3.3) Intermodal maritime } \\
\text { transport chains }\end{array}$ & \\
\hline Others & $(4.1-)$ & \\
\hline
\end{tabular}


Table 3.

Customers and their representatives for scientific counseling.

\begin{tabular}{lc}
\hline \multicolumn{1}{c}{ Target customer categories } & Target customer representatives \\
\hline $\begin{array}{l}\text { Industry: Companies in the commercial part of the maritime transport sector } \\
\begin{array}{l}\text { Government: Regional, national, and supra-national authorities and public } \\
\text { organizations in the maritime transport sector }\end{array}\end{array}$ & $\begin{array}{l}\text { Board members, top managers, and transport and logistics } \\
\text { analysts }\end{array}$ \\
$\begin{array}{l}\text { Academia: Universities and similar institutions providing education in logistics and } \\
\text { transport }\end{array}$ & Politicians, policy makers, and transport analysts \\
Media & Journalists reporting on logistics and transport \\
\hline
\end{tabular}

\section{Project Development}

Project development is another service of the RMUN Virtual Competence Centre, strategic business unit 2 (SBU 2). It represents the third mission of the RMUN.

\section{Service Definition}

Project development is an expert service providing advisory support for various steps in the project development process in the maritime transport sector such as initiating, funding, organizing, carrying through and reporting R\&D. The aim of such projects is to create new knowledge for maritime transport management and education.

\section{Service Delivery}

Project development advisory services are provided by the RMUN project development group, led by the RMUN project development coordinator. The role of the group and its coordinator is to give advisory and administrative support to all steps in the project development process. The demand for service can be communicated to the coordinator via a portal or at personal meetings, and the service can be delivered either via the Internet or through personal contact. The project development coordinator will continuously follow the development in the maritime transport sector and its needs for R\&D and inform RMUN partners about such needs via the internal area of the network web site. Two kinds of project development services will be provided:

- Continuous surveillance of the maritime sector's needs for R\&D made by the project development coordinator;

- Advisory and administrative project support on an ad hoc basis.

\section{Customers}

Project development initiatives can be taken by researchers or teachers from individual or groups of RMUN partners. Such initiatives refer in particular, but not only, to common projects supposed to be carried out by all or some of the RMUN partners. This means that customers are internal RMUN customers. Only employees in RMUN partner organizations, who are entitled to plan and lead R\&D projects in their own organizations, can be authorized to use the project development service. This does not, of course, exclude RMUN members from involving non RMUN members as participants in such projects. Communication to all members in project development going on in the project development group is required, even if not all RMUN members are involved.

\section{Value Added}

The objective of the RMUN project development advisory service is to add value by increasing internal RMUN members ability to base their education on scientific research by:

- identifying project ideas;

- identifying sources for project financing;

- offering expertise for organizing and monitoring project work;

- giving support to reporting project results to the scientific community, the industry and the public.

\section{Marketing Strategies}

\section{The Aim of Marketing and the Importance of Brand Development}

The aim of marketing is to create interest, awareness and demand for the products of the RMUN product mix. Formulated in this way, the aim reflects a lot of methodological wisdom about the marketing task. It points to the dynamic problem of moving from an initial situation, where the RMUN concept is almost unknown by the market, to the ideal situation where there is a sufficient and lasting demand for the RMUN products characterized by customer and market loyalty. RMUN products are complicated knowledge services, and thus intangible. They are produced by a virtual organization which is also rather intangible. This makes it necessary to create a set of image dimensions in which potential customers and consumers can create a mental picture of the RMUN and its output, a picture that is reflecting RMUN as an academic network for innovative maritime education and $\mathrm{R} \& \mathrm{D}$. This mental picture is the RMUN brand, a perceived intangible concept.

If a RMUN succeeds in creating a strong brand, the brand will automatically carry out a lot of the marketing work.

In the beginning of the brand building process, marketing communication between RMUN members and potential customers, consumers and communication mediators will be the most important method for marketing and brand building. Personal communication in particular will be extremely important for RMUN brand building in the beginning of the RMUN life-time. The RMUN slogan and the three components of the RMUN mission provide general promotional content to the personal communication. Non personal written communication using the RMUN web site, the RMUN logo and various marketing artifacts can support and facilitate personal communication, but the latter will be the most important marketing method considering the products and target groups of the problem.

However, in the longer perspective a strong RMUN brand will first and foremost be created by offering the market a rele- 
vant product mix and delivering this mix in a way that meets the expectation of the customers. There is no escape from that. Since this will take time, RMUN brand development will need support from marketing communication between RMUN members and potential customers, consumers and communication mediators.

\section{Organization of the RMUN Marketing Work}

An important implication of the discussion so far is that marketing, and especially personal marketing communication, has to be decentralized to RMUN members. The reason for this is, firstly, that most market contacts will be based on RMUN members' personal and organizational relationships with existing and potential customers and, secondly, that contextual knowledge about markets and customers makes the solution of marketing problems more efficient and effective. This is true for the industry segment of employees as students. For university students the conclusion is the same but for a slightly different reason. Here student populations, in particular newcomers, are all part of the local catchment areas of RMUN universities. This also calls for decentralization of marketing to the members. However, in both cases the decentralized marketing task will become easier over time since it will be possible to draw on the, hopefully, increasing strength of the RMUN brand. RMUN marketing will be relationship marketing.

\section{Communication Strategies}

\section{Courses}

RMUN marketing communication will take place in a complicated social system with possible transmission of information and influence through series of face to face dyadic contacts. In such diffusion processes it will be efficient to identify two target groups for the RMUN communication strategy, target customers and target consumers. The customers are the decision makers who have the power to choose or not to choose RMUN as a supplier, but the consumers may influence these decisions for or against RMUN in the complicated social system that is at work here. Therefore, possible communication channels to both customers and consumers of courses are shown in Tables 4 and 5.

\section{Scientific Counseling}

Communication strategies for scientific counseling are easier to develop than for courses since the target group is much smaller, more homogeneous and easier to identify. Table 6 below presents possible communication channels for various target groups.

\section{Project Development}

Since the customers of the RMUN project development service are employees in the member universities, there are no difficulties with communication channels. All communication will be internal.

\section{Pricing Strategies}

The aim of the RMUN pricing strategies is to design principles and a structure for pricing so that the revenues from selling the RMUN services can be expected to give a predetermined contribution to cost coverage, and also, perhaps, to generate a surplus that can be used for further development of RMUN. Pricing must be simple and transparent.

\section{Cost Coverage}

Two categories of costs must be covered: Common costs and separable cost.

Common costs represent the use of resources that are required to maintain a minimum RMUN production preparedness and marketing activity according to the RMUN mission. The costs of the central coordinating unit (coordinator, secretariat, and web site) and part of the costs of SBU 1 and SBU 2 can be regarded as common costs. They are by definition independent of the volume of output of the three service categories in the product mix. There are at least three possible alternatives for

Table 4.

Possible communication channels to target customers of RMUN courses.

\begin{tabular}{|c|c|}
\hline RMUN target customers & Possible communication channels \\
\hline $\begin{array}{l}\text { University customers: } \\
\text { Course developers and course leaders in logistics and } \\
\text { transport economics and management and other } \\
\text { subjects relevant to the maritime transport sector }\end{array}$ & $\begin{array}{l}\text { Personal: } \\
\text { - } \text { Organization of scientific conference sessions about RMUN } \\
\text { - } \quad \text { Short seminars about RMUN at universities } \\
\text { Informing about RMUN in all contexts where RMUN representatives meet members from } \\
\text { Non personal: } \\
\text { - } \quad \text { Articles in scientific journals } \\
\text { - } \quad \text { Articles in newspapers and magazines written by journalists } \\
\text { - } \quad \text { Internet communication (written and photographic) }\end{array}$ \\
\hline $\begin{array}{l}\text { Industry customers: } \\
\text { Competence managers and developers in the maritime } \\
\text { transport sector }\end{array}$ & $\begin{array}{l}\text { Personal: } \\
\text { - } \quad \text { Organization of industry conference sessions about RMUN } \\
\text { - } \quad \text { Short seminars or presentations about RMUN in industry } \\
\text { - } \quad \text { Personal communication at face to face meetings with industry managers } \\
\text { Non personal: } \\
\text { - Articles in industry journals } \\
\text { - } \quad \text { Articles in newspapers and magazines written by journalists } \\
\text { - Posters at trade fairs, exhibitions etc. } \\
\text { - } \quad \text { Internect leaflets, newsletters, press releases }\end{array}$ \\
\hline
\end{tabular}


Table 5.

Possible communication channels to target consumers of RMUN courses.

\begin{tabular}{|c|c|}
\hline RMUN target consumers & Possible communication channels \\
\hline $\begin{array}{l}\text { University students in: } \\
\text { - Logistics and transport } \\
\text { - Other subjects relevant to the maritime transport sector } \\
\text { such as international trade and international business }\end{array}$ & $\begin{array}{l}\text { Personal: } \\
\text { - } \quad \text { Presentations about RMUN at course and program information meetings } \\
\text { - Information to student unions etc. } \\
\text { Non personal: } \\
\text { - } \quad \text { Articles in industry journals } \\
\text { - } \quad \text { Articles in newspapers and magazines written by journalists } \\
\text { - } \quad \text { Posters at trade fairs, exhibitions etc. } \\
\text { - } \quad \text { Project leaflets, newsletters, press releases }\end{array}$ \\
\hline & $\begin{array}{l}\text { Personal: } \\
\text { - } \\
\text { - } \quad \text { Infesentation of RMUN at industry conference sessions }\end{array}$ \\
\hline $\begin{array}{l}\text { Industry students: } \\
\text { Employees in the maritime transport sector in need of com- } \\
\text { petence development }\end{array}$ & 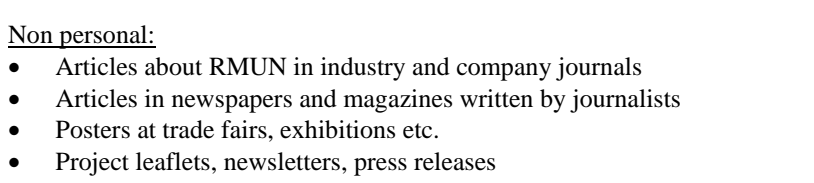 \\
\hline
\end{tabular}

Table 6.

Possible communication channels to target customers for scientific counseling.

\begin{tabular}{|c|c|c|}
\hline Target customer categories & Target customer representatives & Possible communication channels \\
\hline $\begin{array}{l}\text { Industry: Companies in the } \\
\text { commercial part of the } \\
\text { maritime transport sector }\end{array}$ & $\begin{array}{l}\text { Board members, top managers, } \\
\text { and transport and logistics analysts }\end{array}$ & $\begin{array}{l}\text { Personal: } \\
\text { - } \quad \text { Organization of industry conference sessions about RMUN } \\
\text { - } \quad \text { Persont seminars/presentations about RMUN in industry } \\
\text { Non-personal: } \\
\quad \text { Articles in industry journals } \\
\text { - Articles in newspapers and magazines written by journalists }\end{array}$ \\
\hline $\begin{array}{l}\text { Government: Regional, } \\
\text { national, and supra-national } \\
\text { authorities and public } \\
\text { organizations in the maritime } \\
\text { transport sector }\end{array}$ & $\begin{array}{l}\text { Politicians, policy makers, and } \\
\text { transport analysts }\end{array}$ & $\begin{array}{l}\text { Personal: } \\
\text { - Organization of conference sessions about RMUN } \\
\text { - Short seminars/presentations about RMUN in Government } \\
\text { Non-personal: } \\
\quad \text { Articles in industry journals } \\
\text { - }\end{array}$ \\
\hline $\begin{array}{l}\text { Academia: Universities and } \\
\text { similar institutions providing } \\
\text { education in logistics and } \\
\text { transport }\end{array}$ & Program and course developers & $\begin{array}{l}\text { Personal: } \\
\text { - } \quad \text { Organization of scientific conference sessions about RMUN } \\
\text { Non-personal: } \\
\text { - Articles in scientific journals } \\
\text { - Articles in newspapers and magazines written by journalists }\end{array}$ \\
\hline Media & $\begin{array}{l}\text { Journalists reporting on logistics } \\
\text { and transport }\end{array}$ & $\begin{array}{ll}\text { Personal: } \\
\quad \text { Organization of industry conference sessions about RMUN } \\
\text { - } \quad \text { Short seminars/presentations about RMUN in industry } \\
\text { Personal communication at face to face meetings with industry managers }\end{array}$ \\
\hline & & $\begin{array}{l}\text { Non-personal: } \\
\text { - Pre-written contents or drafts for articles }\end{array}$ \\
\hline
\end{tabular}

covering the common costs:

- Alternative 1: From external funding;

- Alternative 2: From fixed yearly contributions from RMUN partners;

- Alternative 3: From a fixed proportion of RMUN revenues (OH rate).

Sources for external funding according to alternative 1 could be regional (such as EU funding programs in Europe) as well as national financiers. RNUN stakeholders could also be a source. Alternative 2 requires that the partner universities are willing to cover the cost of a fixed minimum capacity. Alternatives 1 and 2 can of course be combined. They require that the yearly common costs can be estimated, at least approximately. Alternative 3 is more complicated since it makes the contributions to com- 
mon costs dependent on revenues that are difficult to estimate in advance. Alternative 3 probably means that invoices either have to be issued centrally by the RMUN secretariat or possible to check by auditors if issued by partners. An interesting solution could be to combine the three alternatives so that they together will generate a reasonable surplus that can be saved as a reserve for consolidation or paid back to the RMUN members.

Separable costs refer to costs that are specific and identifiable for separable activities such as the delivery of services to customers by RMUN members. Such services are proposed to be priced by the service supplier in an agreement between supplier and customer, and the supplier can use the revenues for cost coverage and contribution to profit (after deduction of contributions to RMUN common costs, if required).

\section{Education}

RMUN modules and MEs must be described in a standardized manner on the RMUN web site. This description will also provide information about the module "owner”, e.g., addresses for communication. The cost of delivering a module or a ME will vary between modules and MEs depending on a lot of factors such as teaching hours, mode of delivery, travel expenses etc. Therefore, the price of course delivery should be decided in an agreement between the provider and the customer for each specific delivery. Any profit should be owned by the course provider. A RMUN partner providing a course may need to buy one or more MEs from other RMUN partners in an internal supplier-customer relation.

Within SBU 1 there will be a common cost for updating and maintaining the MEs to secure a basic production preparedness of the system. This may be the case for MEs containing elearning elements. The principles for covering common costs of updating and maintaining MEs will be defined in the RMUN network agreement, and yearly budgets for these activities will be decided by the RMUN board.

If alternative 3 is chosen by RMUN for common cost contributions, then a payment system for $\mathrm{OH}$ rates has to be developed so that the necessary contributions to RMUN common costs from course revenues will be paid to the central coordinating unit at about the same rate as the revenues are received.

\section{Scientific Counseling}

Each partner will pay a fixed amount per year for the right to a template on the RMUN website. The price to customers of the service itself is assumed to be determined in direct negotiation between the service provider and the customer, and the payment for the service rendered will be made directly from the customer to the provider. The fixed $\mathrm{OH}$ rate for common cost coverage will not be applied for scientific counseling.

\section{Project Development}

The continuous surveillance of the maritime sector made by the project development coordinator will be a service which is available to all RMUN partners. The cost of producing this service is a common cost and covered by the alternative that is chosen for covering such costs. The price of ad hoc project support on demand will be determined in a negotiation between the customer and the provider(s), and the payment will be made directly from customer to provider. Use of the fixed $\mathrm{OH}$ rate could be discussed for ad hoc project development.

\section{Dynamic Price Strategy Implementation}

The first step in implementing the price strategy is to calculate the yearly common costs of the central coordinating unit and the two SBUs. Given this cost, it is reasonable to require that it must be covered mainly from alternatives 1 and 2 for cost coverage year 1 and that the income expected from applying the $\mathrm{OH}$ rate on revenues (alternative 3 ) are underestimated with a reasonable safety margin. Any RMUN profit will be carried over to the budget for year 2 for reducing partners' own contributions to the coverage of common cost or as profit for partners at the end of year 2. This strategy can be followed in subsequent years.

\section{Concluding Remarks}

Collaboration networks such as RMUN can deliver value to their customers' educational portfolio by increasing their ability to offer such courses and educational programs which they are unable to produce themselves without access to the kind of subcontractor services offered by the network. The collaboration network can deliver added value to customers and consumers by offering:

- Specialized modules and module elements (MEs) of high quality for the specific field and sector, courses that target customers are unable to produce themselves because of lack of expertise or financial resources for developing and running such courses;

- Modules and MEs made available to customers when and where they need them. This means that the education services must be possible to integrate in a flexible way in the educational production cycles of the customers;

- Modules and MEs that consumers find interesting and stimulating to study;

- Modules and MEs that are expected by consumers to be competitive in their labor markets;

- Flexible and differentiated teaching and learning methods.

These characteristics can be seen as specific generic "value adders" for collaboration network such as the RMUN.

From the three different modes of delivery and teaching: conventional face-to-face classroom teaching, via the Internet as e-teaching and conventional face-to-face classroom teaching by a visiting lecturer-traveling lecture concept, a combination of two or three of these modes of delivery can be used which leads to a forth category: Blended teaching. These modes of delivery can be combined with exchange of students between universities where students study one or several MEs at another campus during a short period of time. This kind of flexible, goal-oriented student exchange will add a new dimension to the regular student exchange programs.

The probability of long-term survival and sustainability of a collaboration network such as the RMUN is very much dependent on stable and high quality of its educational offers. High quality of its service packages is the single most important factor for building a strong brand and ultimately its competitiveness and attractiveness.

Sharing and distributing risk and revenues is a difficult aspect in collaboration network such as the RMUN because it is difficult to define and construct a framework that everyone can agree upon and that works in all possible settings. The model and role as subcontractor and subordinate unit to the universi- 
ties is one option to cope with this issue where decisions and design are designed bilaterally for individual cases.

Experiences from our case, the Northern Maritime University project, also illustrate the importance of separating the strategic and marketing focus of the collaboration network with that of the individual universities. It is important to define the network as subordinate/subcontractor to the individual universities in order not to compete and be in direct conflict with the individual university goals, strategies and brand.

In sum, collaboration networks such as Regional Maritime University Network (RMUN) proposed in this paper can deliver great value for its customers and consumers by its three fundamental business units: educational services, scientific counseling and project development.

\section{Acknowledgements}

The authors of this paper thank the participants of the Northern Maritime University project for interesting and rewarding co-operation and the Interreg IVB North Sea Region Programme for funding the project. These participants are: Edinburgh Napier University, Great Britain; University of Applied Science, Kiel, Germany; University of Southern Denmark, Denmark; Molde University College, Norway; Bremen University of Applied Science, Germany; Luebeck University of Applied Science, Germany; International Jacobs University, Bre- men, Germany; University of Gothenburg, Sweden; IVL, Swedish Environmental Research, Sweden; and PANTRAK, Great Britain.

\section{REFERENCES}

Aaker, D. A. (2001). Strategic market management. New York: John Wiley.

Franklin, S., \& Peat, M. (2001). Managing change: The use of mixed delivery modes to increase learning opportunities. Australian Journal of Educational Technology, 17, 37-49.

Garrison, R., \& Kanuka, H. (2004). Blended learning: Uncovering its transformative potential in higher education. The Internet and Higher Education, 7, 95-105. doi:10.1016/j.iheduc.2004.02.001

Kotler, P., \& Keller, K. L. (2006). Marketing management. Upper Saddle River, NJ: Prentice Hall.

Osguthorpe, R., \& Graham, C. (2003). Blended learning environments: Definitions and directions. Quarterly Review of Distance Education, 4, 227-233.

Shaheen, R. (2010). Creativity and education. Creative Education, 1, 166-169. doi:10.4236/ce.2010.13026

Stake, R. (1995). The art of case study research. Thousand Oaks, CA: Sage.

Yin, R. K. (1989). Case study research: Design and method. Newbury Park, CA: Sage. 